\title{
Research Article: Cluster front line demonstration in blackgram variety Vbn 6 at Vellore district of Tamil Nadu
}

\author{
口. VEERAMANI, S. JOSHUA DAVIDSON, G. ANAND AND M. PANDIYAN
}

Article Chronicle: Received :

11.07.2017;

Accepted :

24.07.2017

KeY WoRds :

Cluster, Front line, Demonstration,

Blackgram variety Vbn 6
SUMMARY : The present study was conducted by KVK, Vellore during 2016 in the Kharif season with seventy five frontline demonstrations in Peruvalayam Village. The results of demonstrations showed that farmers could increase the blackgram productivity notably by switching over to improved variety and adoption of improved production technology. From the front line demonstrations, it was observed that the improved Blackgram variety VBN 6 recorded the higher yield $(738 \mathrm{~kg} / \mathrm{ha})$ compared to the farmers' practices variety $(431 \mathrm{~kg} / \mathrm{ha})$. The increase in the demonstration yield over farmer's practices was 41.5 per cent. Technology gap and the technology index values were $133 \mathrm{~kg} / \mathrm{ha}$ and 15.2 , respectively. The decline in overall yield and area under cultivation of blackgram in Vellore district from the year 2010 to 2015 was due to the high incidence of yellow vein mosaic (YVM) disease. The increment in yield of blackgram crop under front line demonstrations was due to spreading of improved and latest technology viz., YVM resistance variety, seed treatment with bio-agents, recommended seed rate, proper dose of fertilizers and plant protection measure. In spite of increase in yield, technological gap, extension gap and technology index existed. The improved technology gave higher gross return, net return with higher benefit/cost ratio than farmers' practices.

How to cite this article : Veeramani, P., Davidson, S. Joshua, Anand, G. and Pandiyan, M. (2017). Cluster front line demonstration in blackgram variety Vbn 6 at Vellore district of Tamil Nadu. Agric. Update, 12(TECHSEAR2) : 475-478; DOI: 10.15740/HAS/AU/12.TECHSEAR(2)2017/475-478. 